\title{
IDENTIFIKASI MISKONSEPSI SISWA MENGGUNAKAN THREE- TIER MULTIPLE CHOICE PADA MATERI KONSEP REDOKS KELAS X MIPA SMA BATIK 1 SURAKARTA
}

\author{
Puput Istika Wulandari ${ }^{\star}$, Bakti Mulyani, dan Budi Utami \\ Program Studi Pendidikan Kimia, FKIP, Universitas Sebelas Maret, Surakarta, Indonesia \\ * Keperluan korespondensi, HP: +6289609788176, email: puput.istika78@gmail.com
}

\begin{abstract}
ABSTRAK
Penelitian ini bertujuan untuk mengetahui: (1) adanya miskonsepsi siswa pada materi konsep redoks di kelas X MIPA SMA Batik 1 Surakarta, (2) sub indikator materi konsep redoks yang menjadi miskonsepsi siswa terbesar di kelas X MIPA SMA Batik 1 Surakarta, dan (3) penyebab miskonsepsi siswa pada materi konsep redoks di kelas X MIPA SMA Batik 1 Surakarta. Penelitian ini merupakan penelitian deskriptif kualitatif. Teknik pengambilan sampel pada penelitian ini menggunakan teknik purposive sampling. Sampel dalam penelitian ini adalah siswa kelas X MIPA 1, X MIPA 2, dan X MIPA 3 SMA Batik 1 Surakarta yang dipilih berdasarkan rekomendasi guru kimia. Teknik pengumpulan data dilakukan dengan menggunakan tes diagnostik three-tier multiple choice, wawancara mendalam (guru dan siswa), analisis RPP serta studi dokumentasi. Hasil penelitian ini menunjukkan bahwa: (1) ditemukan adanya miskonsepsi siswa pada materi konsep redoks di kelas X MIPA SMA Batik 1 Surakarta; (2) miskonsepsi siswa pada materi konsep redoks terbesar di kelas X MIPA SMA Batik 1 Surakarta ditemukan pada sub indikator penerapan dan persamaan reaksi redoks yaitu sebesar 46,89\%; (3) penyebab miskonsepsi siswa pada materi konsep redoks di kelas X MIPA SMA Batik 1 Surakarta yaitu berasal dari siswa, guru, model pembelajaran, serta buku pegangan guru dan siswa.
\end{abstract}

Kata Kunci: miskonsepsi, three-tier multiple choice, konsep redoks

\section{PENDAHULUAN}

Dewasa ini, pendidikan berperan sangat penting bagi manusia. Melalui pendidikan, daya pikir dan pengetahuan manusia dapat berkembang sehingga dapat mengimbangi pesatnya perkembangan informasi dan teknologi. Di Indonesia, sampai saat ini kualitas pendidikannya masih tergolong rendah yang ditunjukan dari data survei PISA. PISA merupakan sebuah program survei tiga tahunan yang diadakan oleh Organization for Economic Co-Operation and Development (OECD) bersama dengan Unesco Institute for Statistics yang memiliki tujuan untuk melakukan studi terkait kualitas pendidikan di setiap negara [1]. Berdasarkan data survei PISA tahun 2015, hasil skor capaian rerata kemampuan sains yang dicapai siswa Indonesia masih di bawah rerata OECD secara keseluruhan [2]. Untuk mengatasi permasalahan tersebut, pemerintah mulai berkomitmen dalam meningkatkan mutu pendidikan Indonesia melalui perubahan kurikulum pembelajaran dari KTSP menjadi kurikulum 2013, khususnya pada penerapan ilmu sains. Salah satunya adalah kimia.

Salah satu sekolah yang sudah menerapkan kurikulum 2013 adalah SMA Batik 1 Surakarta. Penerapan kurikulum 2013 di kelas lebih menuntut siswa untuk bertindak aktif dalam mencari informasi terkait materi yang dipelajarinya selama proses pembelajaran dibandingkan dengan ketika penerapan KTSP. Hal ini menunjukkan bahwa kurikulum 2013 lebih menekankan pada pembelajaran yang sangat berpusat pada siswa atau yang dikenal dengan istilah Student Centered Learning (SCL) daripada Teacher Centered Learning (TCL) yang sebelumnya lebih sering diterapkan pada kurikulum KTSP. 
Dengan penerapan SCL di kelas, pencarian informasi yang dilakukan oleh masing-masing siswa tentu tidaklah sama antar siswa. Hal ini tentu memungkinkan terjadinya perbedaan pemahaman konsep yang diterima oleh masing-masing siswa meskipun mereka mempelajari materi yang sama. Perbedaan pemahaman ini disebabkan karena adanya perbedaan pembentukan konsep awal yang terjadi pada masingmasing siswa. Konsep awal yang dimiliki siswa akan berimbas pada pemahaman awal terkait materi yang dipelajarinya. Pemahaman awal inilah yang disebut dengan prakonsepsi siswa [3].

Prakonsepsi yang dibangun siswa terkadang dapat menimbulkan pemahaman konsep yang tidak utuh atau miskonsepsi [4]. Miskonsepsi adalah konsep yang tidak sesuai atau berbeda dengan konsep dan pemahaman yang diyakini benar oleh masyarakat ilmiah atau pakar di bidang tersebut [5]. Miskonsepsi dapat dialami oleh siapa saja, baik siswa yang pintar ataupun siswa yang biasa saja. Siswa yang mengalami miskonsepsi berbeda dengan siswa yang tidak paham konsep. Siswa yang mengalami miskonsepsi cenderung yakin dengan pemahaman yang dia miliki terkait konsep tertentu meskipun pemahaman tersebut sebenarnya tidak sesuai dengan konsep yang benar, sedangkan siswa yang tidak paham konsep cenderung tidak memiliki pegangan atau pengetahuan dasar apapun terkait konsep yang dipelajarinya.

Kimia merupakan ilmu yang berkaitan erat dengan kehidupan seharihari [6]. Maka dari itu, siswa dituntut untuk memahami kimia bukan hanya menghafalkan konsepnya saja tetapi juga dalam penerapannya dalam kehidupan. Dalam penerapan kimia di sekolah, siswa kebanyakan mengalami kesulitan dalam memahami konsepkonsep kimia yang dipelajarinya [7]. Kesulitan yang dialami siswa dalam memahami konsep kimia disebabkan karena sifat dari ilmu kimia yang kompleks dan abstrak dimana struktur materi dan zat-zat kimia tidak semuanya dapat dilihat oleh mata secara langsung.
Tingkat kesulitan kimia khususnya pada materi konsep redoks diperkuat dengan data hasil prestasi belajar siswa salah satu SMA favorit di Surakarta yaitu SMA Batik 1 Surakarta. Data prestasi belajar siswa SMA Batik 1 Surakarta ditunjukkan dengan data daya serap siswa pada UNBK kimia materi konsep redoks dari tahun 2016 - 2018. Data daya serap siswa pada UNBK kimia materi konsep redoks dari tahun 2016 - 2018 berturut-turut yaitu 86,14 [8]; 71,43 [9]; dan 57,72 [10]. Hal ini menunjukkan bahwa mungkin ada kesalahan dalam diri siswa dalam memahami materi konsep redoks sehingga daya serap siswa selama tiga tahun terakhir semakin mengalami penurunan.

Materi konsep redoks merupakan salah satu materi kimia yang dianggap sebagai materi awal dan rumit karena materi ini merupakan materi prasyarat dalam mempelajari materi-materi berikutnya, seperti persamaan reaksi kimia kelas X-XII, materi redoks dan materi elektrokimia-elektrolisis di kelas XII [11]. Karakteristik materi konsep redoks dianggap rumit karena memiliki keterkaitan satu sama lain antara konsep dan perhitungan matematika, serta memerlukan pemahaman yang lebih di dalamnya khususnya pada perhitungan bilangan oksidasi [12]. Kerumitan yang timbul pada materi konsep redoks sangat berpotensi menimbulkan miskonsepsi pada siswa. Apabila miskonsepsi siswa tidak segera diidentifikasi, maka akan berpengaruh terhadap proses pemahaman dan prestasi belajar siswa.

Salah satu teknik yang dapat digunakan untuk mengidentifikasi letak miskonsepsi siswa adalah instrumen three-tier multiple choice. Teknik threetier multiple choice merupakan gabungan dari teknik two-tier dan teknik Certainty of Response Index (CRI) [13]. Three-tier multiple choice merupakan salah satu jenis tes diagnostik yang digunakan untuk membedakan antara siswa yang kurang pengetahuan (tidak paham konsep) dengan siswa yang mengalami miskonsepsi [14]. Hal tersebut merupakan salah satu keunggulan dari instrumen ini karena pada dasarnya dalam dunia pendidikan sangat penting 
untuk membedakan tingkat pemahaman siswa sehingga dapat dipilih metode pengajaran yang tepat dalam proses pembelajaran di kelas. Oleh karena itu, tes diagnostik tiga tingkat (Three-tier multiple choice) dianggap lebih akurat untuk mengidentifikasi miskonsepsi siswa karena dilengkapi dengan pertanyaan keyakinan [15].

Berdasarkan uraian yang telah dijabarkan diatas, maka perlu dilakukan penelitian yang bertujuan untuk mengidentifikasi miskonsepsi siswa dengan menggunakan three-tier multiple choice pada materi konsep redoks di kelas $X$ MIPA SMA Batik 1 Surakarta.

\section{METODE PENELITIAN}

Penelitian ini merupakan penelitian deskriptif kualitatif. Teknik pengambilan sampel pada penelitian ini menggunakan teknik purposive sampling. Populasi dalam penelitian ini adalah seluruh siswa kelas X MIPA SMA Batik 1 Surakarta. Sampel dalam penelitian ini adalah siswa kelas X MIPA 1, X MIPA 2, dan X MIPA 3 SMA Batik 1 Surakarta yang dipilih berdasarkan teknik pengambilan sampel yang digunakan dan rekomendasi guru kimia yang menganggap bahwa ketiga kelas tersebut sudah mampu mewakili populasi dalam penelitian ini.

Teknik pengumpulan data dalam penelitian ini dilakukan dengan menggunakan tes diagnostik three-tier multiple choice, wawancara mendalam (guru dan siswa), analisis RPP serta studi dokumentasi. Tes three-tier multiple choice berfungsi untuk mengetahui data awal letak miskonsepsi yang dialami siswa. Kemudian wawancara mendalam berfungsi untuk memperkuat data hasil tes diagnostik three-tier multiple choice terkait adanya miskonsepsi siswa. Penilaian analisis RPP digunakan untuk melengkapi data terkait miskonsepsi siswa dilihat dari model pembelajaran yang digunakan guru dalam menyampaikan materi konsep redoks di kelas. Terakhir, penggunaan studi dokumentasi berfungsi untuk memperkuat data miskonsepsi dari tes diagnostik dan wawancara sehingga dapat digunakan sebagai bahan pertimbangan terkait penyebab timbulnya miskonsepsi siswa.

Teknik uji validitas data keseluruhan menggunakan validasi isi. Untuk uji validitas soal tes diagnostik three-tier multiple choice mengginakan validasi isi dan reliabilitas soal. Perhitungan uji validitas isi instrumen tes three-tier multiple choice, wawancara mendalam, dan studi dokumentasi dilakukan dengan menggunakan formula Gregory dimana hasil perhitungan validitas isi dari ketiga instrumen diperoleh masing-masing sebesar 1,00. Uji reliabilitas soal tes diagnostik three-tier multiple choice dihitung menggunakan ITEMAN dan diperoleh nilai reliabilitas soal sebesar 0,783 . Hal ini menunjukkan bahwa semua instrumen layak digunakan dalam penelitian ini.

Teknik analisis data pada penelitian ini terdiri dari pengelompokkan data, penyajian data, verifikasi data, dan penarikan kesimpulan.

\section{HASIL DAN PEMBAHASAN}

Pengambilan data tes three-tier multiple choice dilakukan selama 3 hari yaitu pada tanggal 29 Maret, 31 Maret, dan 6 April 2018. Pengambilan data tes dilakukan di kelas X MIPA 1, X MIPA 2, dan $X$ MIPA 3 dengan masing-masing waktu pengerjaan tes selama 90 menit. Data hasil tes kemudian dikategorikan menjadi 4 kategori sesuai aturan threetier multiple choice yaitu menguasai konsep (MK), miskonsepsi (MS), menebak (MB), dan tidak tahu konsep (TT) [16].

Berdasarkan keseluruhan hasil jawaban tes siswa, menunjukkan bahwa ada beberapa siswa yang mengalami miskonsepsi pada tiap butir soal. Besarnya persentase miskonsepsi yang dialami siswa berbeda-beda di tiap butir soal dan sub indikator. Hasil pengkategorian pemahaman siswa pada tiap butir soal berdasarkan hasil tes dapat dilihat pada Tabel 1. 
Tabel 1 Hasil Pengkategorian Pemahaman Siswa pada Tiap Butir Soal

\begin{tabular}{|c|c|c|c|c|c|c|}
\hline \multirow{2}{*}{ No. } & \multirow{2}{*}{ Sub Indikator } & \multirow{2}{*}{$\begin{array}{l}\text { Butir } \\
\text { Soal }\end{array}$} & \multicolumn{4}{|c|}{ Kategori Pemahaman Siswa (\%) } \\
\hline & & & MK & MS & MB & TT \\
\hline & Perkembangan konsep reaksi & 1 & 26,02 & 45,53 & 2,43 & 26,02 \\
\hline & reduksi dan oksidasi & 2 & 43,09 & 26,02 & 5,69 & 25,2 \\
\hline & & 3 & 47,97 & 18,7 & 15,48 & 17,85 \\
\hline \multicolumn{3}{|c|}{ Rerata Persentase Sub Indikator 1} & 39,03 & 30,08 & 7,87 & 23,02 \\
\hline \multirow[t]{6}{*}{2.} & Penentuan bilangan oksidasi & 4 & 30,9 & 50,4 & 5,69 & 13,01 \\
\hline & atom & 5 & 62,6 & 24,39 & 7,32 & 5,69 \\
\hline & & 6 & 68,29 & 12,2 & 5,69 & 13,82 \\
\hline & & 7 & 56,1 & 30,09 & 4,88 & 8,93 \\
\hline & & 8 & 57,72 & 28,46 & 1,63 & 12,19 \\
\hline & & 9 & 48,78 & 31,7 & 2,43 & 17,09 \\
\hline \multicolumn{3}{|c|}{ Rerata Persentase Sub Indikator 2} & 54,07 & 29,54 & 4,6 & $\mathbf{1 1 , 7 9}$ \\
\hline & Penerapan dan persamaan & 10 & 46,34 & 35,77 & 6,5 & 11,39 \\
\hline & reaksi redoks & 11 & 52,03 & 27,64 & 9,76 & 10,57 \\
\hline & & 12 & 60,16 & 15,45 & 14,63 & 9,76 \\
\hline & & 13 & 14,63 & 65,86 & 3,25 & 16,26 \\
\hline & & 14 & 8,94 & 67,48 & 0,81 & 22,77 \\
\hline & & 15 & 11,38 & 69,11 & 3,25 & 16,26 \\
\hline \multicolumn{3}{|c|}{ Rerata Persentase Sub Indikator 3} & 32,24 & 46,89 & 6,37 & 14,5 \\
\hline \multirow{3}{*}{\multicolumn{2}{|c|}{ 4. Oksidator dan reduktor }} & 16 & 38,21 & 43,9 & 5,69 & 12,2 \\
\hline & & 17 & 60,98 & 24,39 & 5,69 & 8,94 \\
\hline & & 18 & 46,34 & 31,7 & 9,76 & 12,2 \\
\hline \multicolumn{3}{|c|}{ Rerata Persentase Sub Indikator 4} & 48,51 & 33,33 & 7,05 & 11,11 \\
\hline \multirow[t]{2}{*}{5.} & \multirow{2}{*}{$\begin{array}{l}\text { Reaksi disproporsionasi } \\
\text { (autoredoks) dan reaksi } \\
\text { konproporsionasi }\end{array}$} & 19 & 39,02 & 32,52 & 13,01 & 15,45 \\
\hline & & 20 & 30,89 & 44,72 & 4,06 & 20,33 \\
\hline \multicolumn{3}{|c|}{ Rerata Persentase Sub Indikator 5} & 34,96 & 38,62 & 8,53 & 17,89 \\
\hline
\end{tabular}

Setelah melakukan tes diagnostik three-tier multiple choice, kemudian peneliti melakukan wawancara guru yang bertujuan untuk meminta pendapat guru terkait pemahaman dan miskonsepsi siswa terkait materi konsep redoks. Selain itu, wawancara ini dilakukan atas dasar karena gurulah yang mengetahui pemahaman awal, kemampuan, dan hasil belajar siswa selama proses pembelajaran di kelas. Wawancara guru ini dilakukan oleh peneliti dengan narasumber guru kimia yang mengajar di kelas X MIPA SMA Batik 1 Surakarta.

Berdasarkan hasil wawancara guru diperoleh informasi bahwa miskonsepsi siswa pada materi konsep redoks biasanya disebabkan karena siswa belum memahami materi sebelumnya, yaitu materi Sistem Periodik Unsur, Ikatan Kimia, dan Larutan Elektrolit-Non
Elektrolit. Materi konsep redoks sangat erat kaitannya dengan ketiga materi tersebut. Apabila siswa tidak memahami dengan benar konsep yang dijelaskan pada ketiga materi tersebut, maka siswa akan kesulitan dalam menentukan perhitungan bilangan oksidasi atom dalam senyawa penyusunnya.

Menurut pernyataan guru, jumlah siswa yang mengalami miskonsepsi dalam satu kelas hanya sekitar 19\% siswa. Akan tetapi, guru belum bisa memastikan jumlah pasti dari siswa yang mengalami miskonsepsi karena guru belum pernah melakukan penelitian langsung terkait miskonsepsi. Guru juga menyatakan bahwa kemungkinan miskonsepsi siswa yang biasanya muncul pada materi konsep redoks adalah pada penentuan bilangan oksidasi atom, khususnya pada aturan pengecualian atom oksigen dan 
hidrogen. Siswa seringkali mengalami miskonsepsi dengan menganggap bahwa bilangan oksidasi atom hidrogen selalu +1 dan bilangan oksidasi atom oksigen selalu -2 .

Kemudian dalam penelitian ini juga digunakan data hasil wawancara siswa. Sistem wawancara siswa dilakukan dengan cara bertanya pada narasumber satu per satu sehingga diperoleh data wawancara yang valid. Wawancara siswa dalam penelitian ini dilakukan dengan 9 orang siswa yang merupakan siswa kelas X MIPA 1, X MIPA 2, dan X MIPA 3. Pemilihan siswa-siswa tersebut didasarkan pada persentase miskonsepsi yang dialaminya sehingga dapat dianggap telah mewakili keseluruhan sampel yang mengalami miskonsepsi pada materi konsep redoks.

Dari hasil wawancara siswa yang telah dilakukan, diperoleh informasi bahwa masing-masing subjek wawancara mempunyai beberapa letak miskonsepsi yang berbeda satu sama lain. Letak miskonsepsi yang dialami subjek wawancara tersebar merata pada tiap sub indikator materi konsep redoks. Selain itu, peneliti juga menemukan data bahwa beberapa siswa memiliki konsep yang benar hanya saja mengalami kesalahan dalam mengaplikasikannya.

Kemudian untuk hasil analisis RPP

Redoks dari guru kimia, diperoleh data bahwa model pembelajaran yang digunakan oleh guru adalah model pembelajaran problem based learning $(\mathrm{PBL})$ dan project based learning (PjBL) dimana pada kegiatan penutup di pertemuan pertama mengajar yang membahas materi senyawa ion sebagai materi pengantar dalam mempelajari materi konsep, guru tidak membuat kesimpulan akhir secara bersama-sama dengan siswa terkait materi senyawa ion yang dipakai sebagai bahan diskusi. Selain itu, guru juga tidak melakukan refleksi terkait materi yang belum dipahami siswa selama mempelajari materi senyawa ion di kelas. Selanjutnya dari hasil studi dokumentasi terhadap buku pegangan guru dan siswa, peneliti menemukan beberapa konsep tidak utuh yang dapat memungkinkan siswa mengalami kebingungan atau salah konsep (miskonsepsi).

Berdasarkan keseluruhan hasil penelitian, menunjukkan bahwa ditemukan adanya miskonsepsi pada masing-masing sub indikator materi konsep redoks yang dialami siswa kelas $X$ MIPA SMA Batik 1 Surakarta dengan penyebab miskonsepsi yang berasal dari siswa, guru, model pembelajaran, serta buku pegangan guru dan siswa. Analisis beberapa miskonsepsi siswa pada masing-masing sub indikator materi konsep redoks akan dibahas sebagai berikut.

\section{Perkembangan Konsep Reaksi Reduksi dan Oksidasi}

Rerata persentase miskonsepsi pada sub indikator ini sebesar 30,08\% yang termasuk kriteria miskonsepsi rendah. Miskonsepsi siswa yang ditemukan dalam sub indikator ini diperoleh jawaban tes dan wawancara siswa dari butir soal nomor 1, 2, dan 3 .

Miskonsepsi pertama yang teridentifikasi berasal dari konsep reaksi reduksi dan oksidasi berdasarkan konsep pelepasan dan pengikatan elektron yaitu siswa beranggapan bahwa reaksi reduksi adalah reaksi yang terjadi karena adanya proses pelepasan elektron, sedangkan reaksi oksidasi adalah reaksi yang terjadi karena adanya proses pengikatan elektron. Hasil penelitian ini sejalan dengan penelitian yang dilakukan oleh Nurlela, Mawardi, \& Kurniati [17] yang juga mendapat data serupa. Padahal konsep yang benar tentang reaksi reduksi dan oksidasi (redoks) berdasarkan prinsip pengikatan dan pelepasan elektron adalah reaksi reduksi merupakan reaksi yang terjadi karena adanya proses pengikatan elektron, dan reaksi oksidasi merupakan reaksi yang terjadi karena adanya proses pelepasan elektron [18].

Miskonsepsi berikutnya yang terindentifikasi berasal dari butir soal nomor 3 yang berisi konsep reaksi reduksi dan oksidasi berdasarkan konsep pelepasan dan pengikatan oksigen. Pada butir soal ini ditemukan dua jenis miskonsepsi dari hasil tes dan wawancara siswa. Miskonsepsi pertama 
pada butir soal ini adalah siswa menganggap bahwa reaksi oksidasi merupakan reaksi yang didalamnya terdapat senyawa yang mengandung oksigen. Miskonsepsi ini ditunjukkan dari jawaban siswa yang memilih dengan benar reaksi $2 \mathrm{SO}_{2}(\mathrm{~g})+\mathrm{O}_{2}(\mathrm{~g}) \rightarrow 2 \mathrm{SO}_{3}(\mathrm{~g})$ sebagai reaksi oksidasi tetapi salah memberikan alasan. Alasan siswa memilih reaksi tersebut sebagai reaksi oksidasi karena pada tiap senyawa yang bereaksi mengandung oksigen dan hasil akhirnya diperoleh jumlah oksigen yang lebih banyak dari sebelumnya. Kusumawati, Enawaty, \& Lestari [19] juga menyatakan bahwa oksidasi dapat terjadi karena senyawa hasil reaksi memiliki jumlah atom oksigen yang lebih banyak dibandingkan jumlah atom oksigen yang dimiliki masing-masing reaktan.

Kemudian, miskonsepsi lain yang ditemukan pada butir soal nomor 3 yaitu siswa salah menafsirkan bahwa reaksi oksidasi merupakan reaksi yang terjadi karena adanya proses pelepasan oksigen dan reaksi reduksi merupakan reaksi yang terjadi karena adanya proses pengikatan oksigen. Temuan miskonsepsi ini juga sejalan dengan penelitian sebelumnya yang menemukan miskonsepsi serupa [17]. Konsep yang benar tentang konsep reaksi reduksi dan oksidasi berdasarkan pelepasan dan pengikatan oksigen adalah reaksi oksidasi merupakan reaksi yang terjadi karena adanya proses pengikatan oksigen, dan reaksi reduksi merupakan reaksi yang terjadi karena adanya proses pelepasan oksigen [18].

\section{Penentuan Bilangan Oksidasi Atom}

Rerata persentase miskonsepsi pada sub indikator ini sebesar $29,54 \%$ yang termasuk kriteria miskonsepsi rendah. Perolehan rerata persentase ini merupakan rerata persentase miskonsepsi terendah dibandingkan dengan rerata persentase miskonsepsi pada sub indikator yang lain.

Miskonsepsi siswa pertama pada sub indikator ini adalah ada beberapa siswa yang beranggapan bahwa bilangan oksidasi atom dalam senyawa tertentu akan semakin kecil seiring dengan adanya perubahan senyawa yang terbentuk. Pemicu miskonsepsi ini adalah siswa yang menganggap bilangan oksidasi atom $\mathrm{O}$ adalah +2 sehingga bilangan oksidasi atom $X$ semakin mengalami penurunan seiring dengan penambahan atom $\mathrm{O}$ dalam senyawa yang terbentuk. Padahal konsep yang benar yaitu bilangan oksidasi atom tertentu akan bertambah seiring dengan adanya pengikatan oksigen. Hal ini didasarkan pada konsep reaksi oksidasi terjadi dengan adanya kenaikan bilangan oksidasi dan pengikatan oksigen.

Kemudian untuk miskonsepsi yang ditemukan pada butir soal nomor 5 yaitu siswa menganggap bahwa bilangan oksidasi atom yang berada dalam golongan VI A di Sistem Periodik Unsur selalu -2. Anggapan siswa ini ditunjukkan dari jawaban siswa yang menyatakan bahwa dalam reaksi 3CuS(s) + $8 \mathrm{HNO}_{3}(\mathrm{aq}) \rightarrow 3 \mathrm{CuSO}_{4}(\mathrm{~s})+8 \mathrm{NO}(\mathrm{g})+$ $4 \mathrm{H}_{2} \mathrm{O}(\mathrm{I})$, unsur yang mengalami kenaikan bilangan oksidasi adalah $\mathrm{Cu}$ karena mengalami perubahan bilangan oksidasi dari +2 menjadi +10 . Pemicu miskonsepsi ini adalah siswa yang menyatakan bahwa bilangan oksidasi atom $S$ dan atom $O$ yaitu -2 karena termasuk golongan VI A, sehingga dalam $\mathrm{CuSO}_{4}$ diperoleh bilangan oksidasi $\mathrm{Cu}$ sebesar +10 .

Berkebalikan dengan anggapan siswa sebelumnya pada butir soal nomor 5 , ada miskonsepsi lain yang ditemukan yaitu siswa yang memilih unsur $\mathrm{N}$ yang mengalami kenaikan bilangan oksidasi dalam reaksi 3CuS(s) $+8 \mathrm{HNO}_{3}(\mathrm{aq}) \rightarrow$ $3 \mathrm{CuSO}_{4}(\mathrm{~s})+8 \mathrm{NO}(\mathrm{g})+4 \mathrm{H}_{2} \mathrm{O}(\mathrm{I})$. Hal ini dikarenakan dari perhitungan siswa yang mengalami miskonsepsi tersebut diperoleh hasil bahwa bilangan oksidasi atom $\mathrm{S}$ dan atom $\mathrm{O}$ adalah +2 , sehingga dari perhitungan bilangan oksidasi $\mathrm{N}$ mengalami kenaikan dari -7 menjadi -2 . Dari hasil perhitungan ini juga menyebabkan miskonsepsi perhitungan bilangan oksidasi pada atom Cu dimana atom $\mathrm{Cu}$ dalam CuS memiliki bilangan oksidasi -2 dan $\mathrm{Cu}$ dalam $\mathrm{CuSO}_{4}$ memiliki bilangan oksidasi -10. Pemicu utamanya adalah bilangan oksidasi atom $S$ dan atom $\mathrm{O}$ dianggap +2 oleh 
kebanyakan siswa karena golongan VI A. Menurut Comins yang menyatakan bahwa penyebab miskonsepsi siswa adalah reasoning atau penalaran siswa yang salah (tidak lengkap) [20].

Konsep yang benar dalam perhitungan bilangan oksidasi atom dalam senyawa adalah apabila yang akan dihitung adalah senyawa ion, maka sebelum menghitung bilangan oksidasi masing-masing atom penyusunnya harus diionisasikan terlebih dahulu sehingga diperoleh bilangan oksidasi atom yang benar berdasarkan muatan ion-ionnya. Contohnya dalam $\mathrm{CuSO}_{4}$ yang merupakan senyawa ion yang terdiri dari ion $\mathrm{Cu}^{2+}$ dan ion $\mathrm{SO}_{4}{ }^{2-}$, perhitungan bilangan oksidasi atom $\mathrm{Cu}$ dapat diperoleh +2 yang merupakan muatan ion $\mathrm{Cu}^{2+}$, kemudian muatan total ion $\mathrm{SO}_{4}{ }^{2-}$ adalah -2 sementara 4 atom $\mathrm{O}$ menyumbang bilangan oksidasi -8 sehingga bilangan oksidasi atom $S$ diperoleh sebesar +6 . Apabila senyawa yang dicari bilangan oksidasinya adalah senyawa kovalen dan senyawa biner, maka perhitungan total bilangan oksidasi bisa langsung sama dengan nol (0) dan dihitung bilangan oksidasi atomnya masing-masing. Contohnya dalam $\mathrm{CO}_{2}$ yang merupakan senyawa kovalen karena tidak dapat diionkan, perhitungan bilangan oksidasi $\mathrm{C}$ diperoleh sebesar +4 karena 2 atom $\mathrm{O}$ menyumbang bilangan oksidasi sebesar -4 . Siswa yang belum memahami konsep-konsep dasar yang terdapat pada materi ikatan kimia akan menyebabkan miskonsepsi berkelanjutan pada materi selanjutnya seperti materi larutan elektrolit-non elektrolit dan materi konsep redoks [21].

Selain itu, miskonsepsi siswa juga terjadi pada aturan pengecualian bilangan oksidasi atom $\mathrm{O}$ dan atom $\mathrm{H}$. Kebanyakan siswa beranggapan bahwa bilangan oksidasi atom $\mathrm{O}$ selalu -2 dan bilangan oksidasi atom $\mathrm{H}$ selalu +1 . Selain itu, juga ada beberapa siswa yang beranggapan bahwa bilangan oksidasi atom $\mathrm{O}$ selalu +2 karena membutuhkan tambahan 2 elektron untuk mencapai kestabilan. Hal ini menunjukkan adanya intuisi yang salah pada siswa karena siswa menganggap bahwa bilangan oksidasi sama dengan elektron.
Menurut konsep yang benar, bilangan oksidasi atom $\mathrm{O}$ memiliki beberapa aturan pengecualian. Dalam senyawa tertentu seperti senyawa $\mathrm{OF}_{2}$, bilangan oksidasi atom $\mathrm{O}$ adalah +2 yang disebabkan perhitungan dimulai dari atom $F$ karena atom $F$ lebih elektronegatif dibanding dengan atom $\mathrm{O}$, sehingga atom $\mathrm{F}$ bermuatan negatif. Untuk senyawa peroksida $\left(\mathrm{H}_{2} \mathrm{O}_{2}\right.$ atau $\mathrm{BaO}_{2}$ ), bilangan oksidasi atom $\mathrm{O}$ sebesar -1 . Selain itu, untuk aturan pengecualian bilangan oksidasi atom $\mathrm{O}$ pada senyawa superoksida seperti $\mathrm{KO}_{2}$, bilangan oksidasi atom $O$ sebesar -1/2. Sedangkan untuk atom $\mathrm{H}$ memiliki aturan pengecualian seperti atom $\mathrm{O}$, yaitu bilangan oksidasi atom $\mathrm{H}$ dapat berubah menjadi -1 apabila terdapat pada senyawa hidrida seperti $\mathrm{NaH}, \mathrm{BaH}_{2}$, atau $\mathrm{AlH}_{3}$ [18].

\section{Penerapan dan Persamaan Reaksi Redoks}

Hasil rerata persentase miskonsepsi siswa pada sub indikator ini sebesar $46,89 \%$ yang termasuk kriteria miskonsepsi sedang. Rerata persentase miskonsepsi ini merupakan rerata persentase miskonsepsi terbesar dibandingkan dengan rerata persentase miskonsepsi pada sub indikator yang lain. Tingginya persentase miskonsepsi siswa pada materi kimia dapat dikarenakan proses pembelajaran kimia yang berlangsung dianggap belum berhasil dalam membuat siswa mengkonstruksikan konsep yang dipelajarinya dengan baik [22].

Miskonsepsi pertama yang teridentifikasi adalah miskonsepsi siswa pada butir soal nomor 10, 11, dan 12 . Miskonsepsi siswa pada ketiga butir soal tersebut adalah siswa beranggapan bahwa jumlah aljabar bilangan oksidasi seluruh atom yang berada pada suatu ion poliatomik adalah sama dengan nol (0). Padahal konsep yang benar tentang penentuan bilangan oksidasi pada ion poliatomik adalah jumlah aljabar bilangan oksidasi seluruh atom-atom dalam suatu ion poliatomik adalah sama dengan muatan ion tersebut [18].

Selanjutnya, juga ditemukan miskonsepsi pada butir soal nomor 14 
yaitu siswa menafsirkan bahwa bilangan oksidasi atom dalam unsur bebas adalah sama dengan bilangan oksidasinya dalam senyawa tertentu. Miskonsepsi ini ditunjukkan dengan siswa yang menyatakan bahwa bilangan oksidasi atom pada unsur bebas $\mathrm{C}$ adalah +4 karena bilangan oksidasi atom $\mathrm{C}$ dalam $\mathrm{CO}_{2}$ juga +4. Begitupun untuk perhitungan bilangan oksidasi atom pada unsur bebas $\mathrm{Cu}$ adalah +2 karena bilangan oksidasi atom $\mathrm{Cu}$ dalam $\mathrm{CuO}$ juga +2. Akibat alasan perhitungan siswa ini, siswa menjawab bahwa reaksi $2 \mathrm{CuO}(\mathrm{s})+\mathrm{C}(\mathrm{s}) \rightarrow 2 \mathrm{Cu}(\mathrm{s})+\mathrm{CO}_{2}(\mathrm{~g})$ bukan merupakan reaksi redoks karena tidak ada perubahan bilangan oksidasi pada atom-atom penyusun dalam reaksi tersebut. Padahal menurut konsep yang benar, bilangan oksidasi unsur bebas adalah 0 [18].

\section{Oksidator dan Reduktor}

Soal tes dan wawancara siswa yang menggunakan sub indikator ini terdapat pada butir soal nomor 16, 17, dan 18. Besarnya rerata persentase miskonsepsi pada sub indikator ini adalah sebesar 33,33\% yang termasuk ke dalam kriteria miskonsepsi sedang.

Miskonsepsi yang ditemukan pada sub indikator ini yaitu siswa beranggapan bahwa oksidator merupakan zat yang mengalami oksidasi, sedangkan reduktor merupakan zat yang mengalami reduksi. Temuan miskonsepsi ini juga sejalan dengan hasil penelitian sebelumnya yang juga menemukan miskonsepsi serupa [17][19]. Padahal konsep yang benar tentang konsep oksidator dan reduktor secara sederhana dapat diartikan dengan oksidator adalah zat yang mengalami reduksi atau yang menyebabkan zat lain mengalami oksidasi, sedangkan reduktor adalah zat yang mengalami oksidasi atau yang menyebabkan zat lain mengalami reduksi [18].

\section{Reaksi Disproporsionasi (Auto- redoks) dan Reaksi Konpropor- sionasi}

Untuk sub indikator ini diwakili oleh 2 butir soal, yaitu butir soal nomor 19 dan 20. Besarnya rerata persentase miskonsepsi pada sub indikator ini sebesar $38,62 \%$ yang termasuk ke dalam kriteria miskonsepsi sedang.

Miskonsepsi siswa yang ditemukan pada sub indikator ini adalah siswa beranggapan bahwa reaksi konproporsionasi adalah reaksi yang didalamnya terdapat reduktor dan oksidator yang merupakan zat yang sama, tetapi hasil reduksi dan hasil oksidasinya merupakan zat yang berbeda. Anggapan siswa ini didasarkan pada penafsiran siswa bahwa dalam reaksi yang merupakan reaksi konproporsionasi terdapat atom dalam satu senyawa sebelum reaksi yang terurai menjadi hasil reaksi yang berbeda setelah bereaksi, dimana hasil reaksi tersebut dianggap sebagai hasil reduksi dan hasil oksidasi oleh siswa. Padahal berdasarkan konsep yang benar, reaksi konproporsionasi adalah reaksi yang didalamnya terdapat reduktor dan oksidator yang merupakan zat yang berbeda, tetapi hasil reduksi dan hasil oksidasinya merupakan zat yang sama.

Untuk pengertian reaksi disproporsionasi (autoredoks), beberapa siswa beranggapan bahwa reaksi disproporsionasi (autoredoks) adalah reaksi yang didalamnya terdapat reduktor dan oksidator yang merupakan zat yang berbeda, tetapi hasil reduksi dan hasil oksidasinya merupakan zat yang sama. Tentu hal ini tidak sesuai dengan konsep yang benar terkait pengertian reaksi disproporsionasi (autoredoks). Konsep yang benar tentang pengertian reaksi disproporsionasi (autoredoks) adalah reaksi yang didalamnya terdapat reduktor dan oksidator yang merupakan zat yang sama, tetapi hasil reduksi dan hasil oksidasinya merupakan zat yang berbeda [18].

Berdasarkan keseluruhan data hasil penelitian dan pembahasan miskonsepsi siswa yang terjadi pada tiap butir soal terkait materi konsep redoks, maka disimpulkan bahwa penelitian ini dapat dikatakan berhasil karena miskonsepsi siswa pada materi konsep redoks di kelas X MIPA SMA Batik 1 Surakarta dapat teridentifikasi dengan menggunakan tes three-tier multiple choice. 


\section{KESIMPULAN}

Berdasarkan hasil penelitian yang telah dilakukan, maka dapat disimpulkan bahwa:

1. Ditemukan adanya miskonsepsi siswa pada materi konsep redoks di kelas $X$ MIPA SMA Batik 1 Surakarta.

2. Miskonsepsi siswa pada materi konsep redoks terbesar di kelas $X$ MIPA SMA Batik 1 Surakarta ditemukan pada sub indikator penerapan dan persamaan reaksi redoks yaitu sebesar $46,89 \%$.

3. Penyebab miskonsepsi siswa pada materi konsep redoks di kelas $X$ MIPA SMA Batik 1 Surakarta yaitu berasal dari siswa, guru, model pembelajaran, serta buku pegangan guru dan siswa.

\section{UCAPAN TERIMA KASIH}

Ucapan terima kasih penulis haturkan kepada seluruh pihak yang telah membantu dalam penelitian ini, khususnya kepada Ibu Ugik Sugiharti, S.Pd., M.Pd. selaku guru kimia kelas $X$ MIPA 1, X MIPA 2, dan X MIPA 3 SMA Batik 1 Surakarta yang telah berkenan bekerja sama serta memberikan izinnya sehingga penulis dapat melakukan penelitian di kelas yang beliau ampu. Tak lupa juga terima kasih untuk siswa-siswa kelas X MIPA 1, X MIPA 2, dan X MIPA 3 SMA Batik 1 Surakarta yang telah membantu dalam penelitian ini.

\section{DAFTAR RUJUKAN}

[1] Wulandari, N. \& Sholihin, H. (2016). Analisis Kemampuan Literasi Sains pada Aspek Pengetahuan dan Kompetensi Sains Siswa SMP pada Materi Kalor. EDUSAINS, 8(1): 66-73.

[2] Kementerian Pendidikan dan Kebudayaan Republik Indonesia. (2016). Peringkat dan Capaian PISA Indonesia Mengalami Peningkatan.

https://www.kemdikbud.go.id/main/ blog/2016/12/peringkat-dancapaian-pisa-indonesia- mengalami-peningkatan diakses pada 8 Maret 2018.

[3] Handayani, R.A., Jamzuri, \& Budiawanti, S. (2014). Profil Prakonsepsi Siswa SMP Kelas VIII pada Materi Cahaya. Jurnal Pendidikan Fisika, 2(2): 25-29.

[4] Dahar, R.W. (2011). Teori-teori Belajar dan Pembelajaran. Jakarta: Erlangga.

[5] Yuliati, L. (2008). Pengembangan Pembelajaran IPA SD. Malang: Universitas Negeri Malang.

[6] Brady, J.E. (1994). Kimia Universitas: Asas dan Struktur. Jakarta: Erlangga.

[7] Eilks, L., Moellering, J., \& Valanides, N. (2007). Seventh-grade Students' Understanding of Chemical Reaction: Reflection from an Action Research Interview Study. Eurasion Journal of Mathematics, Science \& Technology Education, 3(4): 271286.

[8] Kementerian Pendidikan dan Kebudayaan Republik Indonesia. (2016). Aplikasi PAMER UN Puspendik Tahun 2016.

[9] Kementerian Pendidikan dan Kebudayaan Republik Indonesia. (2017). Aplikasi PAMER UN Puspendik Tahun 2017.

[10] Kementerian Pendidikan dan Kebudayaan Republik Indonesia. (2018). Aplikasi PAMER UN Puspendik Tahun 2018.

[11] Purnamawati, H., Ashadi, \& Susilowati, E. (2014). Pengaruh Model Pembelajaran Kooperatif Tipe Teams Games Tournament (TGT) dengan Media Kartu dan Ular Tangga ditinjau dari Kemampuan Analisis Siswa Terhadap Prestasi Belajar Siswa pada Materi Pokok Reaksi Redoks Kelas X Semester 2 SMA 
Muhammadiyah 1 Karanganyar Tahun Pelajaran 2013/2014. Jurnal Pendidikan Kimia (JPK), 3(4): 100108.

[12] Yulianingtyas, E., Budiasih, E., \& Marfuah, S. (2017). Pengaruh Penggunaan Jurnal Belajar dalam Model Pembelajaran Learning Cycle 6E terhadap Kesadaran Metakognitif Siswa SMAN 8 Malang pada Materi Redoks. Jurnal Pendidikan: Teori, Penelitian, dan Pengembangan, 2(8): 724-730.

[13] Hasan, S., Bagayoko, D., \& Kelley, E.L. (1999). Misconceptions and The Certainty of Response Index (CRI). Physics Education, 34: 294299.

[14] Ardiansah, Masykuri, M. \& Rahardjo, S.B. (2018). Senior High School Students' Need Analysis of Three-Tier Multiple Choice (3TMC) Diagnostic Test About Acid-Base and Solubility Equilibrium. ICOSMEE IOP Conf. Series: Journal of Physics, 1022: 1-8.

[15] Saat, R.M. dkk. (2016). Development of An Online Three-Tier Diagnostic Test to Assess PreUniversity Students' Understanding of Celluler Respiration. Journal of Baltic Science Educaion, 15(4): 532-546.

[16] Arslan, H.O., Cigdemoglu, C., Moseley, C. (2012). A Three-Tier Diagnostic Test to Assess PreService Teachers' Misconception about Globar Warming, Greenhouse Effect, Ozone Layer Depletion, and Acid Rain. International Journal of Science Education, 34(11): 1667-1686.
[17] Nurlela, Mawardi, \& Kurniati, T. (2017). Kajian Miskonsepsi Siswa Melalui Tes Multiple Choice menggunakan Certainty of Response Index (CRI) pada Materi Reaksi Reduksi Oksidasi Kelas X MIPA SMAN 1 Pontianak. Ar-Razi Jurnal IImiah, 5(2): 225-238.

[18] Sudarmo, U. (2016) Kimia untuk SMA/MA Kelas X: Kelompok Peminatan Matematika dan IImuIImu Alam. Jakarta: Erlangga.

[19] Kusumawati, I., Enawaty, E. \& Lestari, I. (2014). Miskonsepsi Siswa Kelas XII SMA Negeri 1 Sambas pada Materi Reaksi Reduksi Oksidasi. Jurnal Pendidikan dan Pembelajaran, 3(6): 1-13.

[20] Suparno, P. (2005). Miskonsepsi dan Perubahan Konsep Pendidikan Fisika. Jakarta: Grasindo.

[21] Medina, P. (2015). Analisis Miskonsepsi Siswa Kelas X pada Materi Larutan Elektrolit dan Non Elektrolit serta Reaksi Oksidasi dan Reduksi dalam Pembelajaran Kimia di SMAN Kota Padang. Jurnal Pendidikan dan Teknologi Informasi, 2(1): 1-9.

[22] Lathifa, U., Ibnu, S. \& Budiasih, E. (2015). Identifikasi Kesalahan Konsep Larutan Asam-Basa dengan Menggunakan Teknik Certainty of Response Index (CRI) Termodifikasi. Seminar Nasional Pendidikan Sains UKWS 2015. 